\title{
KOMUNIKASI INTERPERSONAL DALAM KELOMPOK MAHASISWA MENGENAI GAYA PSYCHEDELIC DI BALI
}

\author{
Nuning Indah Pratiwi \\ Universitas Pendidikan Nasional \\ nuningindahpratiwi@undiknas.ac.id \\ Kadek Adyatna Wedananta \\ Universitas Pendidikan Nasional \\ adyatnawedananta@undiknas.ac.id
}

\begin{abstract}
ABSTRAK
Istilah Psychedelic sendiri berarti suatu keadaan kejiwaan dimana orang mengalami halusinasi dan hilang kesadaran akibat pengaruh dari luar, contohnya obat-obatan, alkohol. Pada era '60an, para seniman menggunakan bantuan obat-obatan agar mencapai keadaan psychedelic, sehingga karya seni yang tercipta dinamakan Seni Psychedelic. Arti psychedelic secara keseluruhan adalah sebuah hal/sifat yang berkaitan tentang mewujudkan pola-pikir, menerjemahkan jiwa. Psychedelic ialah kemampuan manusia memvisualisasikan hal-hal yang ada di pikiran menjadi vision (penglihatan), yang akan terasa sangat nyata (efek halusinasi). Pengalaman psychedelic sering dibandingkan dengan bentuk kesadaran seperti trance (keadaan tidak sadar diri), meditasi, yoga, dan bermimpi. Komunikasi adalah istilah yang begitu popular saat ini, di mana ada pertukaran pesan dari komunikator kepada komunikan melalui media sehingga mendapatkan umpan balik. Media massa, buku, kelompok diskusi, pelatihan, lokarnya, seminar, dan sebagainya membahas komunikasi. Manusia modern diberondong oleh pesanpesan komunikasi dari berbagai jurusan, baik secara terang-terangan, ataupun secara halus, baik secara verbal ataupun non verbal. Manusia berkumpul dan membentuk komunikasi kelompok dapat diartikan sebagai sekumpulan orang yang mempunyai tujuan yang sama, yang berinteraksi satu sama lain untuk mencapai suatu tujuan bersama, mengenal satu sama lainnya, dan memandang mereka menjadi salah satu bagian dari kelompok tersebut. Contoh: tetangga, keluarga, kawan-kawan dekat, kelompok diskusi, kelompok pemecahan masalah, atau suatu komite untuk mengambil suatu keputusan, komunikasi ini dengan sendirinya melibatkan komunikasi interpersonal (antar pribadi).
\end{abstract}

Kata Kunci: Gaya Psychedelic, Komunikasi Kelompok, Mahasiswa 


\begin{abstract}
The term Psychedelic itself means a mental state in which people experience hallucinations and loss of consciousness due to external influences, for example drugs, alcohol. In the era of the '60s, artists used the help of medicines to achieve a psychedelic state, so the artwork created was called the Psychedelic Art. The psychedelic meaning as a whole is a thing / trait that is concerned with realizing mind-patterns, translating souls. Psychedelic is the ability of humans to visualize things that exist in the mind into vision (vision), which will feel very real (hallucinatory effects). Psychedelic experiences are often compared to forms of consciousness such as trance, meditation, yoga, and dreaming. Communication is a term that is so popular today, where there is an exchange of messages from communicators to communicants through the media so that they get feedback. The mass media, books, discussion groups, training, location, seminars, etc. discuss communication. Modern humans are bombarded by communication messages from various majors, either openly, or subtly, both verbally and non-verbally. Humans gather and form group communication can be interpreted as a group of people who have the same goal, who interact with each other to achieve a common goal, know each other, and view them as one part of the group. For example: neighbors, family, close friends, discussion groups, problem solving groups, or a committee to make a decision, this communication naturally involves interpersonal communication.
\end{abstract}

Keyword: Psychedelic Style, Group Communication, Students

\title{
Latar Belakang Masalah
}

Ketika manusia dilahirkan, ia tidak serta-merta dibekali kemampuan untuk berkomunikasi secara baik. Manusia akan tumbuh dan berkembang sesuai usia begitupun kemampuannya dalam berkomunikasi. Komunikasi adalah peristiwa sosial, peristiwa yang terjadi ketika manusia berinteraksi dengan manusia yang lain. Komunikasi memainkan peranan penting dalam kehidupan manusia. Hampir setiap saat manusia bertindak dan berinteraksi dengan dan melalui komunikasi. Kegiatan komunikasi yang dilakukan sebagian besar berlangsung dalam situasi komunikasi interpersonal, yaitu komunikasi antar dua orang yang sering kali terjadi dalam keluarga. Komunikasi efektif terjadi ketika makna yang ditangkap oleh penerima pesan sama dengan makna yang diinginkan oleh pengirim pesan. Hal demikian sering kali terjadi saat komunikasi tatap muka (face to face communication). Oleh karena itu, komunikasi interpersonal dianggap sebagai komunikasi yang paling efektif diantara bentukbentuk komunikasi lainnya, sebab efek dan timbal balik yang ditimbulkan dari proses komunikasi interpersonal dapat secara langsung dirasakan. Komunikasi interpersonal terjadi 
apabila seseorang dapat memprediksi tentang reaksi orang lain terhadap sesuatu sesuai dengan sejarah atau data psikologis orang lain tersebut. Bentuk komunikasi interpersonal inilah yang paling sering digunakan antara orang tua single parent dan anak diantara macam-macam bentuk komunikasi antarmanusia lainnya. Banyaknya fenomena budaya yang telah terimplementasi dalam kehidupan sehari-hari tidak lepas dari pola pikir dari masing-masing individu. Di masa kontemporer ini isu-isu muncul sebagai kesadaran atas pertentangan sistem sosial yangdianggap merugikan publik global, seperti kapitalisasi yang erat dengan asumsi postmodernisme dan modernism. Hal ini berimplikasi pada signifikansi pengaruh budaya pop (pop-culture) yang cenderung memperkenalkan gaya hidup heterogen sehingga memunculkan akulturasi budaya yang menarik, dan dapat dipadukan oleh prinsip-prinsip kehidupan sosial kapitalis yang diperkenalkan oleh budaya barat. Implikasi pop-culture menumbukan paham konsumerisme dan hedonisme di segala lapisan sosial tanpa ada batas-batasan yang dipercayai oleh globalisasi.

\section{Rumusan Masalah}

Berdasarkan belakang masalah di atas, maka yang menjadi pokok permasalahan dalam penelitian ini adalah bagaimana komunikasi interpersonal dalam kelompok mahasiswa mengenai gaya psychedelic di Bali?

\section{Tujuan Penelitian}

Tujuan penelitian pada artikel ini adalah untuk mengkaji dan menganalisis komunikasi interpersonal dalam kelompok mahasiswa mengenai gaya psychedelic di Bali.

\section{Kajian Teori}

\section{Gaya Psychedelic}

Kata psychedelic berasal dari bahasa Yunani (psycho, artinya pikiran, jiwa, dan mental), dan delic (delein, artinya memanifestikan, mewujudkan/merealisasikan). Secara singkat, psychedelic bisa disebut "manifesti jiwa" atau merealisasikan "vision of mind." Istilah Psychedelic sendiri berarti suatu keadaan kejiwaan dimana orang mengalami halusinasi dan hilang kesadaran akibat pengaruh dari luar, semisal obat-obatan. Pada era '60an, para seniman menggunakan bantuan obat-obatan agar mencapai keadaan psychedelic, sehingga karya seni yang tercipta dinamakan Seni Psychedelic. Arti psychedelic secara keseluruhan adalah sebuah 
hal/sifat yang berkaitan tentang mewujudkan pola-pikir, menerjemahkan jiwa. Psychedelic ialah kemampuan manusia memvisualisasikan hal yang ada di pikiran menjadi vision (penglihatan), yang akan terasa sangat nyata (efek halusinasi). Pengalaman psychedelic sering dibandingkan dengan bentuk kesadaran seperti trance (keadaan tidak sadar diri), meditasi, yoga, dan bermimpi. Psychedelic merupakan sebuah aliran seni yang ngetrend pada periode '60an sampai akhir '75an. Aliran ini muncul dipelopori oleh anak-anak muda yang menganut gaya hidup hippies, yaitu sebuah gaya hidup bebas yang keras menantang keteraturan budaya, radikal, dan membenci pemerintahan (akibat perang yang terus-menerus terjadi pada masa itu).

Hippie merupakan sebuah kultur yang muncul di Amerika Serikat sekitar tahun pertengahan 1960an. Mereka biasa mendengarkan musik psychedelic rock. Terkadang para hippie menggunaan narkoba dan ganja yang dapat memberikan mereka efek terbang sehingga merangsang imajinasi. Dalam sebuah imajinasi seseorang yang sedang dalam pengaruh narkoba biasanya terlihat hal-hal abstrak penuh warna-warni dan memberikan efek euphoria. Hal tersebut dimanifestasikan dalam karya seni psychedelic art kaum hippie. Kaum Hippie ini juga kerap menggunakan pakaian yang berwarna-warni kebanyakan dari teknik ikat celup yang menghasilkan bentuk-bentuk tidak terduga.

\section{Pengaruh Gaya Psychedelic}

Sebagai contoh pengaruh psychedelic dapat dilihat dalam penerapan kehidupan seharihari yaitu antara lain adalah sebagai berikut:

\section{a. Style Dandanan Rambut}

Gaya dan teknik psychedelic sangat berpengaruh sekali terhadap kehidupan kita seharihari, terutama kepada kaum wanita. Salah satu nya adalah pada penataan rambut. Teknik penataan rambut pada kepang merupakan salah satu teknik dan gaya dari psychedelic. Tidak hanya kepang, rambut keriting juga merupakan teknik psychedelic. Rambut keriting bergaya psychedelic sering dijumpai pada salah satu personil music rock. Di Indonesia, musisi music rock yang terpengaruh dengan teknik dan gaya rambut psychedelic tahun 80-an adalah musisi musik rock "SLANK". 


\section{b. Mode Pakaian dan Kain}

Semakin bergeraknya perkembangan zaman, pengaruh psychedelic sangat besar sekali pada model warna pakaian. Banyak para pembatik dan pendesain pakaian menggunakan warnawarna psychedelic yang cerah dan warna-warni sehingga pakaian dan kain yang telah diberi warna tersebut terlihat indah, elegan, dan dapat memikat banyak orang. Teknik psychedelic pada kain sering dijumpai pada batik yang terbuat dari bahan saten. Teknik psychedelic pada model pakaian ini menjadi salah satu motif tekstil yang popular.

c. Tata Rias (Make Up)

Pengaruh psychedelic yang ketiga adalah pada tata rias (make-up). Teknik psychedelic tersebut sering digunakan pada eyeshadow. Tidak hanya pada wanita saja yang menggunakan teknik psychedelic pada make-up, pada pria teknik ini juga digunakan, misalnya pada saat acaraacara tertentu seperti acara pesta topeng, hallowen, cosplay anime dan lain-lain.

d. Tatto

Hal lain yang tidak kalah dari pengaruh psychedelic adalah tatto. Psychedelic tatto menjadi personal commitment anak muda masa kini. Gambar yang terukir dipermukaan kulit tersebut memang pengaruh dari psychedelic. Dengan warnanya yang beraneka ragam dan cerah dapat membuat tatto terlihat bersih dan indah.

\section{Karakteristik Komunikasi Interpersonal}

Wenburg dan Wilmat (1973) memaparkan bahwa komunikasi interpersonal adalah proses pertukaraninformasi di antara dua orang sehingga pesan atau informasi dapat di ketahui umpan baliknya dalam interpersonal ini adanya kedekatan sehingga pesan melalui pribadi akan mengarah pada tingkat hubungan yang mana pesan yang disampaikan sampai tataran sikap dan perilaku demikian interaksi yang efektif (Muhammad,2002:159).

\section{Teori Fenomenologi}

Alfred Schutz mengatakan bahwa reduksi fenomenologis, pengesampingan pengetahuan manusia tentang dunia, meninggalkan individu dengan apa yang ia sebut sebagai suatu "aruspengalaman" (stream of experience). (Mulyana, 2007:35). Sebutan fenomenologis berarti studi tentang cara dimana fenomena hal- hal yang disadari muncul kepada manusia, dan cara yang paling mendasar dari pemunculannya sebagai suatu aliran pengalaman-pengalaman inderawi 
yang berkesinambungan yang diterima melalui panca indera. Fenomenologi tertarik dengan pengidentifikasian masalah ini dari dunia pengalaman inderawi yang bermakna, suatu hal yang semula terjadi di dalam kesadaran individual manusia secara terpisah kemudian secara kolektif, di dalam interaksi antara kesadaran-kesadaran.

Jadi "hubungan-hubungan makna" (meanings contexs), serangkaian kriteria yang mengorgnisir pengalaman inderawi manusia ke dalam suatu dunia yang bermakna. Hubunganhubungan makna diorganisir secara bersama-sama, juga melalui proses tipikasi, ke dalam apa yang Schutz namakan "kumpulan pengetahuan” (stock of knowledge). Kalau manusia tetap pada tingkat kumpulan pengetahuan umum (commomsense knowledge), maka akan diarahkan kepada studi-studi dalam lingkup kecil, mengenai situasi-situasi tertentu, yang merupakan jenis karya empiris. Perkembangan fenomenologi menjadi suatu teori mengenai masyarakat.

\section{Metode Penelitian}

\section{Tahapan Penelitian}

Tahapan penelitian yang dilakukan antara lain sebagai berikut:

1. Mengidentifikasi Masalah

Mengidentifikasi masalah adalah peneliti melakukan pengamatan terlebih dahulu kemudian menemukan fenomena yang terjadi di masyarakat dan menemukan permasalahan kemudian merumuskan masalah yang akan diteliti. Tahap ini merupakan tahapan utama dalam penelitian, karena semua jalannya penelitian akan dituntun oleh perumusan masalah.

\section{Studi Literatur}

Pada tahapan ini peneliti melakukan kajian pustaka, yaitu mempelajari buku-buku referensi dan hasil penelitian sejenis sebelumnya yang pernah dilakukan oleh orang lain. Tujuannya untuk mendapatkan landasan teori mengenai masalah yang akan diteliti. Teori merupakan dasar seorang peneliti memahami persoalan yang diteliti dengan benar dan sesuai dengan kerangka berpikir ilmiah. 
3. Menyusun Rancangan Penelitian

Pada tahapan ini peneliti menyusun sebuah rancangan penelitian yang akan dipergunakan sebagai sebuah acuan dalam membantu melaksanakan dan menyusun penelitian.

4. Menyusun Strategi Teknik Pengumpulan Data

Pada tahapan ini peneliti menyusun sebuah strategi yang akan dipergunakan untuk mengumpulkan data-data yang diperlukan dalam penelitian ini. Dalam penelitian ini peneliti menggunakan teknik pengumpulan data yaitu:

\section{a. Observasi}

Menurut Bungin (2013: 142), observasi atau pengamatan adalah kegiatan keseharian manusia dengan menggunakan pancaindra mata sebagai alat bantu utama selain pancaindra lainnya. Oleh karena itu, observasi adalah kemampuan seseorang untuk menggunakan pengamatannya melalui hasil kerja pancaindra mata serta dibantu dengan pancaindra lainnya. Metode observasi adalah metode pengumpulan data yang digunakan untuk menghimpun data penelitian, dimana data penelitian tersebut dapat diamati oleh peneliti. Suatu kegiatan pengamatan baru dikategorikan sebagai kegiatan pengumpulan data penelitian apabila memiliki kriteria sebagai berikut:

- Pengamatan digunakan dalam penelitian dan telah direncanakan secara sistematik.

- Pengamatan harus berkaitan dengan tujuan penelitian yang telah ditetapkan.

- Pengamatan tersebut dicatat secara sistematik dan dihubungkan dengan proporsi umum dan bukan dipaparkan sebagai suatu yang hanya menarik perhatian.

- Pengamatan dapat dicek dan dikontrol mengenai validitas dan reliabilitasnya.

Dalam penelitian dikenal bentuk observasi langsung, yaitu pengamatan yang dilakukan secara langsung pada obyek yang diobservasi. Hal ini dimaksud bahwa peneliti secara langsung melihat atau mengamati apa yang terjadi pada obyek 
penelitian. Pada penelitian ini, digunakan pengamatan langsung tentang gaya psychedelic mahasiswa dalam komunikasi kelompok.

b. Wawancara

Metode wawancara adalah proses memperoleh keterangan untuk tujuan penelitian dengan cara tanya jawab sambil bertatap muka antara pewawancara dengan responden atau orang yang diwawancarai, dengan atau tanpa pedoman (guide) wawancara. Pedoman wawancara adalah instrument yang digunakan untuk memandu jalannya wawancara (Bungin, 2013: 133-134). Beberapa bentuk wawancara dalam penelitian di antaranya adalah wawancara sistematik, wawancara semistruktur, wawancara terarah, dan wawancara mendalam.

Penelitian ini menggunakan metode wawancara sistematik dan semistruktur, yaitu wawancara yang dilakukan dengan terlebih dahulu mempersiapkan pedoman (guide) tertulis tentang apa yang hendak ditanyakan kepada informan, dan wawancara yang dilakukan secara bebas tapi terarah dengan tetap berada dalam jalur pokok permasalahan, yaitu terkait dengan gaya psychedelic mahasiswa dalam komunikasi kelompok.

c. Studi Dokumentasi

Metode dokumenter menurut Bungin (2013: 153-154), adalah metode yang digunakan untuk menelusuri data historis, oleh karena sebenarnya sejumlah besar fakta dan data sosial tersimpan dalam tubuh pengetahuan sejarah yang berbentuk dokumentasi. Sifat utama dari data ini tak terbatas pada ruang dan waktu, sehingga dengan melakukan studi dokumentasi akan memberi peluang kepada peneliti untuk menelusuri hal-hal yang telah silam.

Dalam penelitian ini, studi dokumentasi difokuskan pada penelurusan terhadap dokumen-dokumen yang terkait dengan gaya psychedelic.

d. Diskusi grup terfokus (focused group discussion)

Menurut Irwanto (2006: 1), ada tiga kata kunci dalam focused group discussion (FGD), yakni (1) diskusi bukan wawancara atau obrolan; (2) kelompok dan bukan individual; dan (3) terfokus bukan bebas. Berdasarkan tiga ciri ini, Irwanto (2006: 1-2) mendefinisikan FGD sebagai suatu proses pengumpulan data dan informasi yang sistematis mengenai suatu permasalahan tertentu yang sangat spesifik 
dengan diskusi kelompok. Sedangkan Stokes (2007: 169), mengemukakan bahwa FGD merupakan diskusi yang dilakukan oleh sekelompok kecil orang yang terorganisasi mengenai topik tertentu.

Pada penelitian ini, peneliti membuat kelompok kecil untuk berdiskusi mengenai implementasi gaya psychedelic dalam komunikasi kelompok pada mahasiswa.

5. Melakukan Analisis Data

Pada tahapan ini peneliti menganalisis data yang telah dikumpulkan melalui wawancara mendalam didukung dengan teori dan kajian pustaka yang sesuai dengan latar belakang masalah.

6. Menulis Laporan Penelitian

Tahap terakhir dalam penelitian ialah membuat laporan mengenai hasil penelitian secara tertulis. Laporan secara tertulis perlu dibuat agar peneliti dapat melaporkan hasil penelitiannya kepada para pembaca atau penyandang dana.

\section{Lokasi Penelitian}

Penelitian ini dilakukan di Denpasar, Bali karena gaya psychedelic dalam komunikasi kelompok mahasiswa di Denpasar, Bali menjadi fenomena yang sangat baru untuk dikaji dan dianalisis terutama dalam komunikasi kelompok.

a. Perubahan yang diamati

Dalam penelitian ini perubahan yang diamati adalah bagaimana gaya psychedelic pada mahasiswa diimplementasikan dalam komunikasi kelompok sehingga menjadi suatu gaya hidup dengan menggunakan teori Fenomenologi.

b. Model Penelitian

Adanya fenomena yang terjadi di kalangan mahasiswa dengan berkembangnya gaya psychedelic dalam komunikasi kelompok dapat dikaji secara fenomenologi yang akan mengkonstruksi dan menginterpretasikan makna yang dihasilkan dari penelitian di lapangan. Berdasarkan pemaparan di atas didapatkan model penelitian sebagai berikut: 


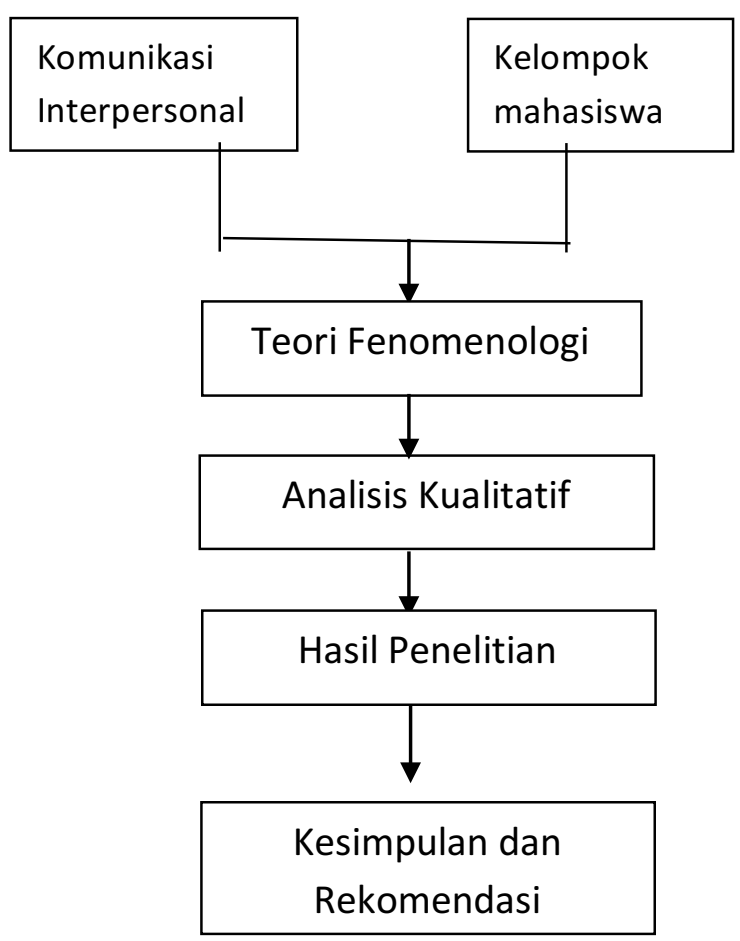

Gambar 6.

Model Penelitian

\section{Jenis dan Sumber Data}

Ada dua sumber data penelitian sebagai sumber informasi yaitu:

\section{a. Data Primer}

Data primer merupakan data yang diperoleh secara langsung dilapangan oleh peneliti sebagai obyek penulisan (Umar, 2003:56). Data primer merupakan data yang diperoleh atau dikumpulkan oleh seorang peneliti atau suatu lembaga tertentu langsung dari sumbernya, dicatat, dan diamati untuk pertamakalinya dan hasilnya digunakan langsung oleh peneliti atau lembaga itu sendiri atau memecahkan permasalahan yang akan dicari jawabannya. Dalam hal ini data yang akan dicari adalah mahasiswa yang menggunakan gaya psychedelic dalam komunikasi kelompok.

b. Data Sekunder

Data sekunder adalah data yang tidak langsung memberikan data kepada peneliti, misalnya penelitian harus melalui dokumen (Sugiyono, 2005:62). Data Skunder yang 
diperoleh dari buku-buku bacaan, tulisan ilmiah, dan studi pustaka yang berkaitan dengan penelitian yang sedang dilakukan (Nawawi, 2005:116). Data yang diperoleh berdasarkan penyampaian liteatur-liteatur, buku dokumen, sumber kepustakaan dan internet.

\section{Informan Penelitian}

Menurut Sugiyono (2012:216) dalam penelitian kualitatif tidak menggunakan populasi atau sampel karena penelitian kualitatif berangkat dari kasus tertentu yang ada pada situasi sosial tertentu dan hasil kajiannya tidak akan diberlakukan pada populasi, tetapi ditransferkan ke tempat lain pada situasi sosial dalam kasus yang dipelajari. Sampel dalam penelitian kualitatif tidak disebut responden melainkan narasumber, partisipan, atau informan.

Sugiyono (2015:144) mengatakan bila penelitian menggunakan metode kualitatif, maka teknik sampling yang sering digunakan adalah purposive sampling, dan snowball sampling. Seperti telah dikemukakan bahwa, purposive sampling adalah teknik pengambilan sampel sumber data dengan pertimbangan tertentu. Pertimbangan tertentu ini misalnya orang tersebut dianggap yang paling tahu tentang apa yang peneliti harapkan atau mungkin dia sebagai penguasa sehingga akan memudahkan peneliti menjelajahi objek/situasi sosial yang diteliti. Oleh karena itu, peneliti mendapatkan informan langsung dari mahasiswa di Denpasar. Karena peneliti menganggap orang yang dipilih dapat memberikan informasi yang diperlukan terkait gaya psychedelic dalam komunikasi kelompok mahasiswa.

\section{Teknik Pengumpulan Data}

Pengumpulan data dimaksudkan untuk memperoleh data, keterangan dan informasi penting dalam penelitian. Terdapat beberapa metode pengumpulan data yang umum digunakan dalam penelitian kualitatif dan kuantitatif yaitu wawancara, observasi, dan dokumentasi. Penelitian ini menggunakan ketiga metode tersebut (Gunawan, 2013:110).

\section{Observasi}

Observasi merupakan metode pengumpulan data esensial dalam penelitian, dengan pendekatan kualitatif, untuk memberikan data yang akurat dan bermanfaat, sebagai metode ilmiah yang dilakukan oleh peneliti yang sudah melewati latihan- latihan dan 
mengadakan persiapan yang matang (Gunawan, 2013:114). Penelitian yang dilaksakan untuk mengumpulkan data melalui pengamatan dari prilaku objek agar memberikan informasi yang pasti melalui sumber yang berkualitas dan akurat.

2. Wawancara

Stainback (dalam Sugiyono, 2013:232) mengemukakan bahwa dengan wawancara, maka peneliti akan mengetahui hal-hal yang lebih mendalam tentang partisipan dalam menginterpretasikan situasi dan fenomena yang terjadi, dimana hal ini tidak bisa ditemukan melalui observasi. Peneliti melakukan wawancara yang mendalam kepada pemangku kepentingan dan elemen masyarakat setelah melalui proses observasi kepada beberapa informan atau narasumber yang akan diberikan pertanyaan, yang berkaitan dengan gaya psychedelic dalam komunikasi kelompok mahasiswa.

\section{Dokumentasi}

Dokumentasi adalah mengumpulkan data dengan cara mengalir atau mengambil datadata dari catatan, dokumentasi, administrasi yang sesuai dengan masalah yang diteliti. Dalam hal ini dokumentasi diperoleh melalui dokumen-dokumen atau arsip-arsip dari lembaga yang di teliti (Suharsimi, 2003:120). Kredebilitas hasil penelitian kualitatif akan semakin tinggi, jika melibatkan dan menggunakan studi dokumen (Gunawan, 2013:179).

4. Diskusi grup terfokus (focused group discussion)

Menurut Irwanto (2006: 1), ada tiga kata kunci dalam focused group discussion (FGD), yakni (1) diskusi bukan wawancara atau obrolan; (2) kelompok dan bukan individual; dan (3) terfokus bukan bebas. Berdasarkan tiga ciri ini, Irwanto (2006: 12) mendefinisikan FGD sebagai suatu proses pengumpulan data dan informasi yang sistematis mengenai suatu permasalahan tertentu yang sangat spesifik dengan diskusi kelompok. Sedangkan Stokes (2007: 169), mengemukakan bahwa FGD merupakan diskusi yang dilakukan oleh sekelompok kecil orang yang terorganisasi mengenai topik tertentu. 


\section{Teknik Keabsahan Data}

Untuk memperoleh keakuratan dalam penelitian, peneliti menggunakan teknik triangulasi. Stainback (dalam Sugiyono, 2013:241) menyatakan bahwa tujuan dari triangulasi bukan untuk mencari kebenaran tentang bebeapa fenomena, tetapi lebih pada peningkatan pemahaman peneliti terhadap apa yang telah ditemukan. Bila peneliti melakukan pengumpulan data dengan triangulasi, maka sebenarnya peneliti mengumpulkan data yang sekaligus menguji kredibilitas data, yaitu mengecek kredibilitas data dengan berbagai teknik pengumpulan data dan berbagai sumber data. Triangulasi menggunakan tiga macam cara dalam pengecekan data, yaitu dari berbagai sumber, cara, dan waktu. Dengan demikian terdapat triangulasi sumber, triangulasi teknik pengumpulan data, dan triangulasi waktu (Moleong, 2011:326-330), berikut penjelasan mengenai Triangulasi:

a) Triangulasi sumber

Untuk menguji kredibilitas data yang dilakukan dengan cara mengecek data yang telah diperoleh melalui beberapa sumber. Dengan melakukan pertanyaan tambahan pada informan atau narasumber lain diluar daftar yang sudah ditentukan. Sebagai data yang telah di analisis oleh peneliti sehingga menghasilkan suatu kesimpulan selanjutnya dimintakan kesepakatan (memberchek) dengan para informan atau narasumber data tersebut. Peneliti menulis mencari informan/narasumber lain guna memberikan kredibilitas data dari perkembangan analisis gaya psychedelic dalam komunikasi kelompok mahasiswa.

b) Triangulasi Teknik

Triangulasi teknik untuk menguji kredibilitas data dilakukan dengan cara mengecek data kepada sumber yang sama dengan teknik yang berbeda. Misalnya data diperoleh dengan wawancara, lalu dicek dengan observasi, dokumentasi, atau kuesioner.

c) Triangulasi Waktu

Waktu juga sering mempengruhi kredibilitas data. Data yang dikumpul dengan teknik wawancara di pagi hari pada saat narasumber masih segar, belum banyak masalah akan memberikan data yang lebih valid sehingga lebih kredibel. 


\section{Teknik Analisis Data}

Suryono (2013:244) menyatakan teknik analisis data dalam penelitian adalah proses mencari dan menyusun secara sistematis data yang diperloleh dari hasil wawancara, catatan lapangan, dan dokumentasi, dengan cara mengorganisasikan data kedalam katagori, menjabarkan ke dalam unit-unit, melakukan sintesa, menyusun kedalam pola, memilih mana yang penting dan yang akan dipelajari, dan membuat kesimpulan sehingga mudah dipahami bagi diri sendiri maupun orang lain. Miles dan Huberman dalam Sugiyono (2013:246) menjabarkan aktifitas analisis data dilapangan sebagai berikut:

\section{a. Reduksi Data}

Mereduksi data berarti merangkum, memilih hal-hal yang pokok, memfokuskan pada hal-hal yang penting, dicari tema dan polanya. Dengan demikian data yang telah direduksi akan memberikan gambaran yang lebih jelas, dan mempermudah peneliti untuk melakukan pengumpulan data selanjutnya, dan mencarinya bila diperlukan.

b. Penyajian data

Penyusunan data merupakan penyusunan informasi yang kompleks kedalam suatu bentuk yang sistematis, sehingga menjadi lebih selektif dan sederhana serta memberikan kemungkinan adanya penarikan kesimpulan data dan pengambilan tindakan. Dengan menyajikan data maka akan memudahkan pemahaman pada apa yang terjadi serta perencanaan selanjutnya berdasarkan apa yang telah dipahami tersebut.

\section{c. Penarikan Kesimpulan}

Tahap akhir dari peroses analisis data di mana peneliti mendapatkan temuan baru yang sebelumnya pernah ada. Peneliti mengutarakan kesimpulannya atas data- data

yang telah diperoleh dari hasil observasi dan studi dokumentasi, menghubungkannya dengan masalah yang menjadi tema penelitian menurut kualitas dan kebenarannya sehingga dapat menjawab permasalahan yang ada. 


\section{Hasil Penelitian dan Pembahasan}

\section{Analisis Gaya Psychedelic pada mahasiswa sebagai arus pengalaman (Stream of Experience)}

Berdasarkan hasil penelitian yang dilakukan dengan metode wawancara dengan informan mengenai gaya psychedelic pada mahasiswa sebagai arus pengalaman (Stream of Experience), didapatkan bahwa mahasiswa di Denpasar mempunyai gaya psychedelic dalam dirinya dengan manifestasi yang berbeda, seperti di musik, gaya tata rias (make up), gaya berpakaian, gaya rambut dan penggunaan tatto di badan. Namun jangan dilupakan, bahwa istilah psychedelic adalah istilah yang digunakan oleh dokter jiwa Humprey Osmond ditahun 1957, yang berkaitan dengan pengalaman perasaan saat menggunakan psychedelic drugs. Jadi segala sesuatu yang berkaitan dengan Psychedelic ini, baik itu musik maupun karya seni rupa, pastilah terhubung dengan pemakaian drugs jenis Psychedelic ini.

Bagi seseorang yang mengalami situasi di era ini, psychedelic dalam situasinya adalah pengalaman yang ditandai oleh persepsi yang datang dari pikiran seseorang di mana sebelumnya tidak pernah dirasakannya. Sebuah kegembiraan besar yang mereka dapatkan lewat pengalaman 'high' yang dirasakan dapat membebaskan pikiran yang terbelenggu. Namun walaupun begitu, pembahasan tentang psychedelic ini tidak berkutat dimasalah drugs saja, walaupun memang benar, akan besar kaitannya dengan drugs. Namun berkembangnya jaman, gaya psychedelic sebenarnya adalah salah satu budaya dari sekian banyak budaya yang ada di dunia. Yang mana diperlukan kajian lebih luas dan dalam. Gaya psychedelic merupakan tentang kebebasan liar di alam pikiran serta jiwa-jiwa yang resah, dan membawa ke alam impian manusia yang luas nan jauh dari segala realitas. Hal ini merupakan sejarah generasi pertama rock $\mathrm{n}$ roll.

Diluar dari pada itu, pada dasarnya, hadirnya sebuah gaya dalam gebrakan budaya visual merupakan cermin kelahiran "angkatan baru" sebagai ekspresi ketidakpuasan terhadap gaya sebelumnya, dengan corak khasnya menjadi alat pembeda generasi satu dengan lainnya. Gerakan psychedelic dalam masa yang singkat, merupakan cerminan perilaku pembangkangan yang lugas, orisinal, dari kebudayaan pemuda Amerika tahun 60an. 
Mengekspresikan jiwa dan pemikirannya secara lugas dan spontan merupakan unsur kebahagian yang hakiki adalah bagaimana menerapkan seluruh pemikiran menjadi kenyataan. Hal ini diimplementasikan dengan gaya tatto badan atau seni merajah tubuh. Pertimbangan dari informan ini ketika membuat seni tatto karena melihat bahwa proses pembuatan tatto merupakan proses yang sangat menantang bagi mereka. Dengan kata lain, bahwa membuat tatto merupakan salah satu sensasi luar biasa dan sangat menguji nyali atau keberanian seseorang dalam menunjukkan eksistensi diri dalam bermasyarakat. Selain itu pemilihan gambar tatto pun tidak sembarangan, tetapi mempunyai arti khusus dan tentunya sangat penting bagi orang yang telah memutuskan untuk membuat tatto.

Yang terpenting komunikasi dengan orang lain sangat mudah karena pemikirannya orang lain menaruh rasa hormat yang lebih ketika berkomunikasi dalam bentuk dan melalui media apapun. Dengan kata lain orang sekitar tidak akan meremehkan, tetapi hal ini juga idukung oleh sikap dan perilaku yang baik ketika berkomunikasi dengan orang lain, walaupun memang tidak dapat dipungkiri penggunaan tatto sangat berpengaruh besar dalam membentuk ekspresi jiwa yang lugas, bebas, dan tegas. Gaya psydehelic di mahasiswa sebagai arus pengalaman yang terjadi dalam kehidupan para mahasiswa ini kumpulan ekspresi jiwa yang sebelumnya sulit untuk diimplementasikan ke dalam kehidupan nyata para mahasiswa ini karena adanya aturanaturan sosial yang berlaku di masyarakat lingkungan sekitar mereka.

\section{Analisis Gaya Psychedelic pada mahasiswa sebagai kumpulan pengalaman (Stock of Experience)}

Kumpulan pengetahuan (stock of knowledge) merupakan hal yang dapat dikaji dalam teori fenomenologi. Jika manusia tetap pada tingkat kumpulan pengetahuan umum (commomsense knowledge), maka akan diarahkan kepada studi-studi dalam lingkup kecil, mengenai situasi-situasi tertentu, yang merupakan jenis karya empiris. Hal ini dikaitkan dengan fenomena gaya psychedelic, di mana terjadinya gaya psychedelic ini dapat juga disebabkan oleh adanya akumulatif pengalaman-pengalaman seseorang dalam dirinya, sehingga dari kumpulankumpulan pengalaman tersebut dapat diimplementasikan atau diaplikasikan dalam kehidupan nyata. Seperti yang dikatakan informan Dian Tri Krismianti, mahasiswa Universitas Warmadewa Bali bahwa gaya psydehelic dalam tata rias muncul dalam dirinya ketika dari SMP 
sering belajar tata rias (make-up), kemudian SMA mendalami tata rias dengan melihat referensi tutorial di media sosial seperti Instagram, terutama akun-akun selebgram dari beauty enthusiast yang terkenal, sampai sekarang setiap beraktivitas harus menggunakan tata rias yang cerah dan berwarna-warni (colourful).

\section{Kesimpulan}

Kesimpulan dari penelitian ini adalah:

1. Gaya psychedelic sudah massive dilakukan oleh banyak orang secara sadar ataupun tidak sadar, khususnya mahasiswa karena sudah semakin banyak mahasiswa yang melakukan keinginan dari dalam dirinya dengan mengimplementasikannya secara nyata.

2. Mahasiswa sudah jarang menerapkan tatanan sosial yang ada di masyarakat seperti gaya penampilan yang sesuai, karena mahasiswa sudah bebas mengekspresikan keinginannya.

3. Gaya psychedelic mahasiswa banyak dipengaruhi oleh gaya penampilan dalam berbusana, tata rambut, tata rias wajah, dan pembuatan tatto.

\section{Saran}

Saran dari penelitian ini adalah:

1. Tetap memerlukan pendidikan karakter dalam keluarga karena sudah banyaknya mahasiswa menerapkan Gaya psychedelic dalam hidupnya dengan tidak memperdulikan tatanan sosial yang ada dimasyarakat sehingga keluarga merupakan wadah untuk memberikan edukasi dalam berperilaku.

2. Mahasiswa bebas berekspresi untuk mengimplementasikan keinginan dalam dirinya tetapi tetap harus menjaga norma kesopanan yang berlaku dalam tatanan masyarakat. 


\section{Daftar Pustaka}

Ali, Mohammad dan Muhammad Asrori. 2011. Psikologi Remaja. Jakarta: Bumi Aksara.

Ardianto, Elvinaro, Q-Anees, Bambang. 2007. Filsafat Komunikasi. Bandung: Simbiosa Rekatama Media.

Arikunto, Suharsimi. 2002. Prosedur Penelitian : Suatu Pendekatan Praktek. Edisi Revisi V. Jakarta: PT. Rineka Cipta.

Azwar, Saifuddin. 1995. Sikap Manusia : Teori dan Pengukurannya. Edisi Kedua. Yogyakarta: Pustaka Pelajar Offset.

Barker, Chris. 2005. Cultural Studies Teori dan Praktek (terj.). Yogyakarta: Bentang.

Berger, Arthur Asa. 2000. Media And Communication Research Methods: An Introduction to Qualitative and Quantitative Approaches. Thousand Oaks, California: Sage Publications, Inc.

DeVito, Joseph, A. 1997. Komunikasi Antar Manusia: Kuliah Dasar. Edisi Kelima, Alih Bahasa Agus Maulana. Jakarta: Professional Books.

Effendy, Onong Uchjana. 2003. Ilmu, Teori, dan Filsafat Komunikasi. Bandung: PT. Citra Aditya Bakti.

2006. Ilmu Komunikasi: Teori dan Praktek. Bandung: PT. Remaja Rosdakarya.

Fajar, Marhaeni. 2009, Ilmu Komunikasi: Teori dan Praktik, Yogyakarta: Graha Ilmu.

Grogan, Paula. 2006. Psychedelic Art Exhibition Investigates 'The Shape Of The Mind'. Issue No. 33/2006 / May/18, 2006.

Liliweri, Alo. 2007. Dasar-dasar Komunikasi Antar Budaya. Yogyakarta: Pustaka Pelajar. 
Maulana, Herdiyan, Gumgum Gumelar. 2013. Psikologi Komunikasi dan Persuasi. Jakarta: Akademia Permata.

McKenna, Terence. 1994. True Hallucination. Inggris: HarperOne.

S. Anggraeni, Lia, Kirana Nathalia. 2016. Desain Komunikasi Visual; Dasar-dasar Panduan untuk Pemula. Bandung: Penerbit Nuansa. 